\title{
Siyasal İfade Amaçlı Sosyal Medya Kullanım Düzeyinin Siyasal İlgi ve Katılım Üzerinde Rolü: Sosyal Medya Platformları Bağlamında Bir Saha Araştırması
}

\author{
DOI: $10.26466 /$ opus. 816083
}

*

\author{
İbrahim Halil Yașar * \\ * Dr. Öğr. Üyesi., Dicle Üniversitesi İletişim Fakültesi \\ Öz \\ ORCID: $\underline{0000-0002-1480-569 X}$
}

Birey-siyaset ilişkisinde bireyin siyasal alanda olup bitenlerle ilgili karar alma süreçlerini takip etmesi ve bunları etkileme çabası merkeze alındı̆̆ında siyasal ilginin ve katılımın yanı sıra sosyal medyanın rolü de ön plana çımaktadır. Kurumsal veya bireysel kullanıma hizmet eden sosyal medya mecralar hemen herkese kendini ifade edebileceği bir alan sunmaktadır. Böylelikle sosyal medya hesabına sahip olmasinın ve içerik üretmesinin son derece kolay olması, bireyin temelde siyasal alanda olup bitenlerle ilgili düşüncelerini açıklayabilmesine imkân sağlamıştır. Bu çalışmada nicel araştırma yöntemi ve kesitsel tarama modeli kullanılarak bireyin siyasal ifade amaçl sosyal medya kullanım düzeyi siyasal ilgi ve katılım çerçevesinde mercek altına alınmak istenmiştir. Ayrıca siyasal düşünceleri paylaşmak amacıyla bireylerin kullandı ̆̆ı platformlar da ilgili değgişkenler bağlamında incelenmeye çalışılmıştır. Sonuç olarak siyasi konularda düşünceleri paylaşmak ya da fikir edinmek için Whatsapp platformunun daha çok kullanıldı̆̆g belirlenirken siyasal katılım ve ilginin Twitter'da en yüksek seviyede olduğu tespit edilmiştir. Siyasal ifade amaçlı sosyal medya kullanım düzeyi yüksek olanlarda siyasal katılım ve ilginin daha yüksek olduğu görülmüştür. Öte yandan cinsiyet, yaş ve eğitim durumunun siyasal ifade amaçlı sosyal medya kullanım düzeyi ile anlamlı bir ilişkiye sahip olmadı̆̆g bulunmuştur.

Anahtar Kelimeler: Sosyal medya, siyasal ifade amaçl sosyal medya kullanım düzeyi, siyasal ilgi, siyasal katılım. 


\title{
The Role of Social Media Usage Level for Political Expression on Political Interest and Participation: A Field Study in the Context of Social Media Platforms
}

\begin{abstract}
In the individual-politics relationship political interest, political participation and the role of social media stand out when the individual's following of the decision-making processes related to what is happening in the political field and the effort to influence them are centered. Social media platforms that serve corporate or individual use provide almost everyone with an opportunity to express themselves. Therefore, the fact that it is fairly easy to have a social media account and produce content has enabled the individual to explain his thoughts about what is basically happening in the political field. In this study, using a cross sectional quantitative research method, it was aimed to examine the level of social media usage for political expression within the framework of political interest and participation. In addition, the platforms used by individuals in order to share political thoughts were examined in the context of the relevant variables. As a result, it was determined that WhatsApp was used more to share thoughts or get ideas on political issues, while political participation and interest in Twitter were at the highest level. It was observed that those who use social media for political expression had higher political participation and interest. On the other hand, it was found that gender, age, and educational degree did not have a significant relationship with the level of social media usage for political expression.
\end{abstract}

Keywords: Social Media, the usage level of social media for political expression, political interest, political participation. 


\section{Giriş}

Kitle iletişim araçlarının toplum ve bireyler üzerinde güçlü etkileri bulunduğu kabul edilmektedir. Kitlesel olarak ideolojilerin üretim formlarına uygun bir biçimde aktarılmasına olanak sağlayan medya üretimlerinde görsel, işitsel ve hareketli imgelerin bir arada kullanılması bu etkiyi güçlendirmekte ve ideolojilerin açık yada örtük biçimde hedef kitleye aktarılması noktasında belirleyici olmaktadır (Akmeşe ve Akmeşe, 2020, s.196). Demokratik toplumlarda bireylerin kendilerini doğrudan veya dolaylı olarak ilgilendiren konularla ilgilenmesi beklenir (Glenn, 1968, s.572). Bireylerin ilgi düzeyinin yüksek olması ve siyasal süreçlere katılması için de sistemin kendi ihtiyaçlarına duyarlı olduğu konusunda olumlu bir yargıya sahip olması ve hissetmesi gereklidir (Yaşar, 2020, s.70). Siyasal ilgi (ya da ilgisizlik) bireyin siyaset kurumu, meclis, iktidar ve muhalefet gibi aktörler ile bu alanda gerçekleşen faaliyetlerle ne düzeyde ilgili olduğuna dikkat çeker. Siyasal katılım ise bireyin sistemle kurmuş olduğu bu ilgiyle yakından ilişkilidir. Bu ilişki çerçevesinde siyasal katılma, siyasal olayları ve hükümet politikalarını takip etme, siyasal eylemde bulunma, siyasi konularda konuşup tartışma, oy verme, oy vermeye ikna etme, adaylığa ve siyasal karar mekanizmalarında yer almaya kadar çeşitli biçim ve boyutlarda kendini gösterebilmektedir (Canbaz, Eyidiker ve Poyraz, 2019, s.2539). Siyasal katılımın belirli düzeyde ilgi, önem, bilgi ve eylemsellik gerektirdiğinin altını çizen Baykal (1970, s.31), katılım düzeylerini sınıflandırmada belirleyici olanın ise bireyin seçimlere katılıp katılmaması, diğer bir ifadeyle kendine sunulan bir siyasal programa oy verip vermemesiyle ilgili olduğunu savunmaktadır. Katılıma ilişkin bir diğer çalışmada Milbrath ve Goel (1977), duygu düzeyinden, siyasal partilerde aktif görev almaya kadar birçok tutum ve davranış siyasal katılıma dahil edilmektedir.

Siyasal ilgi ve siyasal katılım, birey siyaset ilişkisinin açıklanmasında sıkça irdelenen tutum ve davranışlara işaret eder. Demokrasilerde yüksek bir ilgi düzeyi, siyasal katılımın öncülü olarak kabul edilmektedir (Coleman ve Davis, 1976, s.192; Öztekin, 2001, s.232). İlgisizliğin ise siyasal güven eksikliği ve siyasal kinizm (cynicism) ile birlikte siyasal hoşnutsuzluğu meydana getirdiği ve bireyin katılımını olumsuz etkilediği düşünülür (Dimitrova ve Bystrom, 2013, s.1570). Öte yandan, siyasal güvenin daha yüksek olduğu senaryoda ise bireyin siyasal ilgi ve katılım düzeyi de daha yüksek seyredebilmektedir (Akgün, 2001, s.6; Advan, 2016, s.168; Hooghe ve Marien, 2013, s.132). 
Siyasal ilgi ve siyasal katılımdan bahsedildiğinde, bireyin siyasal alanda olup bitenlerle ilgili karar alma süreçlerini takip etmesinin ve bunları etkileme çabasının merkeze alındığını belirtmek gerekir. Bir siyasal eylemin ortaya çıkabilmesi içinse temelde üç koşulun söz konusu olması gerektiğinin altı çizilmektedir (Kalaycıŏglu, 2013). Bunlardan ilki olay ve olguları değerlendirme ve yorumlama becerisi olarak (logical inference) ifade edilen bilişsel bilgi; ikincisi bireyin siyasal olayları izleme konusundaki alışkanlıkları ve siyasete olan ilgisi ile kendini siyasal kararlar üzerinde ne derece etkili gördüğünün ifadesi olan siyasal etkinlik duygusundan oluşan siyasal ve psikolojik kaynaklar; son olarak ise bireyin sahip olduğu sosyal ağ bir başka deyişle tanıdığı ve bağlantıda olduğu kişi sayısı ve bu ilişkilerin mahiyeti olarak ifade edilmektedir; birey sahip olduğu bu ilişkileri kullanarak çevresini hareketlendirebilecek, yalnız ve güçsüz olmadığını hissedecektir (Kalaycıŏlu, 2013, s.149-151). Vatandaşlar arasında "siyasal etkinlik" duygusunun yüksek düzeyde olması, demokrasinin istikrarı açısından arzu edilen bir durum olarak kabul edilirken, "modern demokratik toplumlarda vatandaşların, hükümetin eylemlerini etkileyebilmek için bir güçleri olduğunu hissetmeleri gerekliliğinin"' (Schulz, 2005, s.4.) altı çizilmektedir. Yapılan çalışmalar, bireysel olarak ya da başkalarıyla uyumlu bir şekilde siyasi değişim sağlayabileceğini düşünen bireylerin politikada aktif olarak yer alma ihtimalinin daha yüksek olduğunu göstermektedir (Campbell vd., 1954, s.194; Milbrath, 1965, s.59).

Siyasete aktif katılım sistemin meşruluğunu güçlendiren bir unsur olmakla birlikte toplumun kolektif bakış açısının siyasi süreçlere yansıması açısindan da önemlidir. Bu bağlamda, birey-siyaset ilişkisini etkileyen ve her biri başlı başına birer inceleme alanı teşkil eden birçok faktör bulunmaktadır. Bu faktörlerin en önemli kabul edilenlerinden bir tanesi birey-siyaset ilişkisinin psikolojik boyutunda yer alan siyasal etkinlik duygusudur (Kalaycığlu, 1983). Birçok akademisyen tarafından kurumsal siyasete katılımın öncüllerinden biri olarak kabul edilen siyasal etkinlik (Campell vd., 1954; Milbrath, 1965; Verba ve Nie 1972), müzakereci demokrasi teorilerinde de önemli bir etken olarak ele alınmış ve değerlendirilmiştir.

Siyasal katılıma ilişkin önemli unsurlardan biri şeffaf bir veri akışı ve bilgi edinme imkânıdır. Bireyin bir konuda yargı sahibi olması, tavır ve tutum geliştirmesi ve nihayetinde bir karara varıp davranışa yönelmesinin yolu, o konuyla ilgili bilgi sahibi olmasından geçmektedir. Bu bağlamda bilgi edinme hakk1, demokrasilerde son derece önemlidir (Lilleker, 2013, s.12-13; Dahl, 
2017, s.47-48). Bilgilenen bireylerin meseleleri farklı açlardan tahlil ederek kendi yargılarını oluşturmaları esastır. Konvansiyonel medya olarak da ifade edilen TV, gazete ve radyo gibi geleneksel medya kanalları yakın bir zamana kadar bu bilgilendirme işlevini önemli ölçüde üstlenmiştir. İlk zamanlarda, medyanın temel işlevi olarak değerlendirilen toplumu bilgilendirme ve haberdar etme görevi, medyanın gerek sahiplik gerekse de ideolojik ve editöryal yaklaşımı gibi nedenlerle eleştirilmekteydi. Ancak, 90'lı yıllarla beraber önce internetin ortaya çıması ve sonrasında yeni medya teknolojilerinin altında filizlenen sosyal medya platformlarının geliştirilmesi, söz konusu bilgi edinme ve haberdar olma sürecine yeni bir boyut katmıştır (Neuman, 2018, s.11).

Sosyal medya platformları çift yönlü ve etkileşimli olmaları dolayısıyla geleneksel mecralardan ayrılmaktadır. Kurumsal ve bireysel kullanıma hizmet eden bu mecralar hemen herkese kendini ifade edebileceği bir alan sunmaktadır. Ağın kendine özgü entegre yapısı, içeriklerin çok hızlı bir şekilde farklı platformlarda yayılmasına olanak sunarken (Castells, 2016, s.1-2) siradan insanlar birer mikro yayıncıya dönüşebilmektedir (Yavaşçalı ve Uğurhan, 2019, s.650). İnternetin sunduğu altyapıyla dijital platformlara doğru geçiş gösteren siyasal yaşam, sosyal medyayla adeta yeni bir boyut kazanmıştır. İlkin siyasal partiler ile aktörlerin başat olduğu ve tek yönlü ilişkilerle vücut bulan bu yapı, sosyal medyayla seçmen potansiyeline sahip bireylerin de dâhil olduğu, edilgenlikten çıkarak söylem ve eylemlerle müdahale yapabildiği daha etkileşimli bir ekosistem haline gelmiştir (Arklan, 2016, s.649).

Siyasal iletişim çalışmaları hem geleneksel hem de yeni medyanın, siyasal kampanyalarda siyasi partiler ve aktörler hakkında bireylerin nasıl bilgi edindiğini belirlediği ve bu sürece katılımlarını etkilediği konusunda hemfikirdir (Dimitrova ve Bystrom, 2013, s.1570). Ancak, sosyal medyanın siyasal alanla ilişkisi oldukça yeni olmakla birlikte etkileyicidir (Nulty, Theocharis, Popa, Parnet ve Beneit, 2016, s.430). İlk olarak ABD başkanlık seçimlerinde Barack Obama'nın seçim çalışmalarında aktif olarak kullanılmasıyla bu alanda adından söz ettiren sosyal medya, sonraki dönemde seçim dönemleri başta olmak üzere siyasal aktörlerin iletişim çalışmalarında önemli bir araç haline gelmeyi başarmış ve seçmenle yakından etkileşim kurmaya olanak tanımıştır (Gerodimos ve Justinussen, 2015, s.113). Her bir platformun sahip olduğu kullanıcı sayıları, ağın entegre yapısı sayesinde içeriklerin son derece hızlı bir şekilde 
yayılması, verilerin otomatik olarak kaydedilmesi dolayısıyla işlenebilir olması gibi sebepler, sosyal medyayı siyasal iletişim açısından son derece kullanışlı kılmaktadır. Böylelikle siyasal partiler sosyal medyayı da içine alan kampanyalarıyla görünürlüklerini artırabilmektedir. Yapılan çalışmalar seçim kampanyalarında politik bir adayın sosyal medyada bulunurluğu ile siyasi partinin bir bütün olarak seçmenler tarafından görünürlüğü arasında bir ilişki olduğunu belirlemiş (Lorenzo-Rodríguez ve Madariaga, 2015; Stier, Bleier, Lietz ve Strohmaier, 2018) ve özellikle günümüz demokrasilerinde sosyal medyanın siyasal seçim kampanyalarında kullanılması temel bir özellik haline gelmiş durumdadır (Bright vd., 2020, s.988). Zira bireyler politik haberlere ulaşmak ve görüşlerini paylaşmak için artan bir şekilde sosyal medyayı kullanmaya başlamıştır (Gerodimos ve Justinussen, 2015, s.114).

Bununla birlikte, bir sosyal medya hesabına sahip olmanın ve içerik üretmenin son derece kolay ve maliyetinin uygulama bazında çoğu zaman ücretsiz olabileceği de göz önünde tutulmalıdır. Nitekim Türkiye'de yapılan 31 Mart 2019 yerel seçimlerinde partiler sosyal medya başta olmak üzere dijital ortamlardan mümkün olan en ideal şekilde yararlanmaya çalışırken pankart, afiş, broşür vb. geleneksel araçlar ile parti araçlarından çalınan müzikleri oldukça kısıtlamışlardır. Böylece hem tasarruf edilmiş hem de çevre ve gürülttü kirliliğinin önüne geçilmeye çalışılmıştır (Avc1, 2019). Bu bakımdan sosyal medya platformları politikacılara seçmenlerle daha yakından bir etkileşim kurma imkânının yanı sıra siyasal partilere nispeten maliyetli olmayan yaratıcı kampanya stratejilerini işe koşma fırsatı sunmuştur (Nulty vd., 2016, s.460).

Sosyal medyanın birey siyaset ilişkisinde oynadığı diğer önemli rol aslında birey açısından oluşturduğu değişikliktir. Bu sayede birey siyasal alanda olup bitenlerle ilgili düşüncelerini açılayabileceği bir kanala kavuşmuştur (Gerodimos ve Justinussen, 2015, s.116). Bireysel açıdan sosyal medyanın siyasal ifade amaçı kullanımı olarak da açıklanan bu kullanım biçimi, bireylerin siyasi konularda düşünce ve yaklaşımlarını açıklamaları ile siyasal parti/aday ve liderleri ve/veya bunların meselelere yaklaşımlarını desteklemek veya eleştirmek gibi çeşitli amaçlarla sosyal medya platformlarını kullanmalarını temsil etmektedir. Yapılan çalışmalar, siyasal ifade amaçlı sosyal medya kullanımının bireyin siyasal ilgisi ve katılımı ile yakından bir ilişkiye sahip olduğunu göstermiştir (Boulianne, 2015; Yaşar, 2020). 
$\mathrm{Bu}$ çalışmada, Türkiye özelinde sosyal medya kullanıcılarının siyasal ifade amaçlı sosyal medya kullanım düzeyleri gruplandırılarak mercek altına alınmak istenmiştir. Elde edilen gruplar çerçevesinde kullanıcıların en çok/en az hangi sosyal medya platformlarını kullandıkları, kullanımlarına göre siyasal ilgileri ve katılımları incelenmeye çalışılmıştır. Öte yandan, kullanıcıların demografik özellikleri açısından siyasal ifade amaçlı sosyal medya kullanım düzeyleri irdelenerek kullanımlarının bir örüntüsü ortaya çıkartılmak amaçlanmıştır. Zira yapılan önceki çalışmalarda sosyal medya kullanıcı profillerine dair demografik veriler göz önünde tutulduğunda sosyal medyanın siyasal partiler ve aktörler tarafından özellikle seçim kampanyalarında daha başarılı bir şekilde kullanılabileceği değerlendirilmektedir (Loader, Vromen ve Xenos, 2014; Kahne ve Middaugh, 2012; Dahlgren, 2007). Bu çalışma aracllığıyla da Türkiye'deki sosyal medya kullanıcılarına yönelik bir seçmen kullanım örüntüsü sunularak a) sosyal medyayı siyasal ifade amaçlı kullanan seçmenlerin özellikleri, b) seçmenlerin hangi platformları daha sık/daha az kullandıkları ve c) siyasal ilgilerinin ve katılımlarının hangi platformlarda düşük/yüksek olduğunu tespit etmek amaçlanmış ve bu değişkenler çerçevesinde bir kanı oluşturmak istenmiştir. Yapılan çalışmalar siyasi partiler tarafından internetin ve sosyal medyanın siyasal amaçlı olarak kullanımı ve seçmene ulaşması neticesinde bireylerin daha fazla siyasal katılıma ve siyasal ilgiye sahip olabileceğini göstermektedir (Vitak vd., 2011; Dimitrova ve Bystrom, 2013). Sosyal medya platformlarının ise bu platformlarda yer alan seçmenlere yönelik özelliklerinin bilinerek kullanılması da siyasal kampanya sürecinde doğru stratejilerle seçmenlere daha hızlı bir şekilde ulaşmayı beraberinde getirebilecektir.

\section{Yöntem}

Bu çalışmada nicel araştırma yöntemi benimsenmiş ve kesitsel tarama modelinden faydalanılmıştır. Kesitsel tarama modeli, bir popülasyonun ya da popülasyondan alınan örneklemin mevcut eğilimlerini, tutumlarını ve görüşlerini nicel bir şekilde, doğrudan tanımlama imkânı vermektedir (Creswell, 2014, s.13). Kesitsel tarama modeli kullanılarak yapılan bu araştırmada, Türkiye'deki sosyal medya kullanıcılarının siyasal ifade amaçlı sosyal medya kullanımları ve siyasi konularda duygu ve düşünceleri paylaşmak ve/veya fikir edinmek için kullandıkları sosyal medya platformları, siyasal katılımları ve siyasal ilgileri yakından incelenmek istenmiştir. 


\section{Amaç ve Önem}

Türkiye'deki sosyal medya kullanıcılarının siyasal ifade amaçlı sosyal medya kullanımlarının incelenmesi bu çalışmanın esas amacıdır. Güncel eğilimleri belirleyebilmek amacıyla kullanıcıların kullandıkları sosyal medya platformları "We Are Social" ve "Hootsuite" tarafından belirlenen ${ }^{1} 2020$ yll itibariyle Türkiye'de en çok kullanılan beş sosyal medya platformu (YouTube, Instagram, Facebook, Twitter ve Whatsapp) kullanılarak değerlendirilmek istenmiştir. İnceleme gerçekleştirilirken bireylerin, siyasal ifade amaçlı sosyal medya kullanım düzeylerine göre sınıflandırılması amaçlanmış ve böylelikle kullanım düzeyi açısından hangi sosyal medya platformunun kullanılıp kullanılmadığı belirlenmeye çalışılmıştır. Öte yandan, yine düzeyler açısından bireylerin siyasal ilgilerinin ve katılımlarının anlamlı bir şekilde farklılaşıp farklılaşmadığının belirlenmesi amaçlanmıştır. Demografik özelliklerle de siyasal amaçlı sosyal medya kullanım düzeyleri arasında nasıl bir ilişkinin olduğuna bakılmıştır. Daha önceki çalışmalar genelde sosyal medyayı siyasal ifade amaçlı kullanım açısından (Arklan, 2016; Nulty vd., 2016; Yaşar, 2020), özelde siyasal etkinlik, siyasal katılım ve siyasal ilgi bağlamında (Balcı ve Saritaş, 2014; Loader vd., 2014; Stier vd., 2018; Olkun, Yüksek ve Aydemir, 2018; Canbaz vd., 2019) doğrudan incelese de bu çalışma sosyal medyayı siyasal ifade amaçlı kullanım düzeyine göre gruplandırarak diğer çalışmalardan farklılaşmaktadır. Böylelikle hem siyasal katılım ve siyasal ilgi değişkenlerine odaklanması hem de düzeyleri gerek demografik özellikler gerekse siyasi konularda duygu ve düşünceleri paylaşmak ve/veya fikir edinmek için kullantlan sosyal medya platformları açısından incelemesi açısından geniş bir çerçeve sunmaktadır.

Bu araştırma Türkiye'de 2020 yılı itibariyle en çok kullanılan beş sosyal medya platformu üzerinden yapılmakta ve söz konusu platformdaki güncel eğilimleri ortaya koyabilmesi açısından önem taşımaktadır. Bu bağlamda çalışmada aşağıdaki araştırma sorularına cevaplar aranmıştır:

- Bireylerin siyasal ifade amaçlı sosyal medya kullanım düzeyleri nasıl dağllım göstermektedir?

- Bireyler siyasal ifade amaçlı sosyal medya kullanım düzeyleri açısından nasıl kümelenmektedir?

\footnotetext{
${ }^{1}$ https://www.slideshare.net/DataReportal/digital-2020-turkey-january-2020-v01 (15.08.2020)
} 
- Siyasal ifade amaçlı sosyal medya kullanım düzeyi ile demografik özellikler ve siyasi konularda duygu ve düşünceleri paylaşmak ve/veya fikir edinmek için kullanılan sosyal medya platformları arasında anlamlı bir ilişki/bağ var mıdır?

- Siyasal ifade amaçlı sosyal medya kullanım düzeyi açısından bireylerin siyasal ilgisi ve katılımı anlamlı bir şekilde farklılaşmakta mıdır?

- Siyasi konularda duygu ve düşünceleri paylaşmak ve/veya fikir edinmek için kullanılan sosyal medya platformları açısından siyasal ilgi ve siyasal katılım anlamlı bir şekilde farklılaşmakta mıdır?

\section{Evren ve Örneklem}

Bu çalışma Türkiye'deki sosyal medya kullanıcılarının siyasal ifade amaçlı sosyal medya kullanımları ve bu bağlamda kullandıkları sosyal medya platformlarıyla ilgili olduğundan dolayı, araştırma evrenini 2020 itibariyle Türkiye'de en çok kullanılan beş sosyal medya platformunu kullanan kullanıc1lar oluşturmaktadır. Ancak, bu kullanıcıların tamamına ulaşılamayacağından ötürü örneklemeye gidilerek olasılıklı olmayan örnekleme yöntemlerinden amaca uygun örnekleme yapılmıştır. Bu örnekleme yönteminde katılımcılar, araştırma amacına uygun, ulaşılması kolay ve gönüllü bireylerden seçilmektedir (Başaran, 2017, s.489). Yapılandırılan anket formu, etik kurul onayı alındıktan sonra sosyal medya kanalları aracılığıyla dolaşıma sokulmuştur. Çalışmada, birer seçmen olarak katılımcılarla ilgili daha tutarlı sonuçlara ulaşabilmek amacıyla bir kontrol sorusu kullanılmış ve çalışmaya gönüllü bir şekilde katılmayı beyan edenlerin ilk önce doğum tarihlerini yıl olarak yazmaları istenmiştir. Doğum tarihini yıl olarak girenler ankete devam edebilmiştir. Böylelikle 2002 yılı ve öncesinde doğanların (2020 yılı itibariyle 18 yaşında ve üstü yaşlarda olanlar) yanıtları incelemeye alınmıştır. Toplamda 530 katılımcıdan veri toplanmıştır.

\section{Veri Toplama Yöntemi ve Aracı}

Araştırma verileri, anket tekniği ile elde edilmiş olup anket formu Google Forms üzerinden dağıtıma sokulmuştur. Türkiye'de 2020 yılı itibariyle en çok kullanılan sosyal medya platformları "We Are Social" ve "Hootsuite" tarafından yapılmış araştırma incelendikten sonra belirlenmiş olup YouTube, 
Instagram, Facebook, Twitter ve Whatsapp olarak anket formuna yerleştirilmiştir. Katılımcıların bu platformları siyasi konularda duygu ve düşüncelerini paylaşmak ve/veya fikir edinmek için kullanıp kullanmadıklarını belirtmeleri istenmiştir (1 - Evet; 2 - Hayır). Öte yandan, ilgili araştırmada bu platformlar dışında Facebook Messenger, Pinterest, LinkedIn gibi platformlar yer alsa da söz konusu beş platform \%60'dan fazla kullanım oranına sahip olduğundan ötürü tercih edilmiştir.

Siyasal ifade amaçlı sosyal medya kullanım düzeyini ve siyasal ilgiyi ölçümleyebilmek amacıyla daha önceki bir çalışmada kullanılan ölçüm araçlarından yararlanılmıştır (Yaşar, 2020). Geçerliği ve güvenirliği ilgili araştırmacı tarafından sağlanan siyasal ifade amaçlı sosyal medya kullanım ölçeği, 7 maddeden oluşmakta ve 5 'li derecelendirme seçeneği şeklindedir (1 - Hiçbir Zaman; 5 - Her Zaman). Siyasal ilgi ölçeği ise 3 maddeden oluşmakta ve 5'li derecelendirme seçeneğine sahiptir (1 - Hiç İlgilenmem; 5 - Her Zaman İlgilenirim). Siyasal katılımı ölçümleyebilmek için Topbaş (2010) ile Balcı ve Sarıtaş (2015)'ın çalışmalarında kullandıkları ölçüm araçlarından faydalanılmıştır. Bu çalışmalardan derlenerek kullanılan ölçek 8 maddeden oluşmakta ve 5'li derecelendirme seçeneği biçimindedir (1 - Hiçbir Zaman; 5 - Her Zaman).

Son haline getirilen anket formu, bir pilot çalışma yapılarak yaşları 22 ile 57 arasında değişen 50 kişi üzerinde test edilmiştir. Böylelikle hem ölçeklerin güvenirliğinin hem de ölçek maddelerinin anlaşllırlığının kontrolü sağlanmıştır. Yapılan Cronbach's $\alpha$ güvenirlik analizi neticesinde a) siyasal ifade amaçlı sosyal medya kullanımı 0,85, b) siyasal ilgi 0,83 ve c) siyasal katılım 0,89 olarak güvenirlik katsayıları elde edilmiştir. Öte yandan, maddelerin anlaşılırlığını kontrol edebilmek için madde-toplam korelasyon değerleri incelenmiş ve her ölçek özelinde ölçek maddeleri ile bir bütün olarak ölçek arasında en az 0,4 ve üzerinde korelasyon değerinin olması kriteri aranmıştır (Hair, Black, Babin ve Anderson, 2014). Sonuç olarak, bütün maddelerin ait oldukları ölçeklerle 0,4'ün üzerinde madde-toplam korelasyonuna sahip oldukları tespit edilmiştir. Elde edilen bu bulgular neticesinde hem ölçeklerin güvenilir hem de maddelerin anlaşılır olduğu sonucuna varılmıştır (Kalaycı, 2017; Hair vd., 2014). Daha sonra esas çalışma uygulanmıştır. 


\section{Veri Analizi ve Kullanılan Testler}

Verilerin temizlenmesinde ve derlenmesinde Microsoft Excel programindan faydalanılırken verilerin analizinde IBM SPSS 25 programından yararlanılmıştır. Kullanılan ölçeklere yönelik geçerlik ve güvenirlik analizleri, açımlayıcı faktör analizi ve Cronbach's Alpha katsayısının kontrolü ile sağlanmıştır. Diğer taraftan, araştırma sorularının yanıtlayabilmek için frekans analizi, kortalamalar kümeleme analizi, ki-kare bağımsızlık testi, tek yönlü varyans analizi (ANOVA) ve bağımsız örneklemler t-test istatistikleri kullanılmıştır.

\section{Bulgular}

Araştırma kapsamında 530 kişiden veri elde edilmiştir. Veriye yapılan ön kontrolde 10 yanıtın uygunsuz bir şekilde doldurulduğu görüldüğü için veri setinden çıkartılmasına karar verilmiş ve kullanılan ölçeklere yönelik tek değişkenli ve çok değişkenli normallik kontrolleri yapılmıştır. Tek değişkenli normallik için her bir ölçeğe ilişkin maddelerin eğiklik ve basıklık değerlerine bakılmış ve 2,2 eşik değerinin dışına çıan bir değerin olmadığı görülmüştür (Sposito, Hand ve Skarpness, 1983, s. 271). Ek kanit toplama amaciyla ilgili ölçek maddelerinin ortalamaları ve $\% 5$ kırpılmış ortalamaları incelenmiş ve bu ortalamalar arasındaki farkın $(<0,1)$ yüksek olmadığı görülmüştür (Pallant, 2011). Öte yandan, çok değişkenli normallik için ölçeklere yönelik Mahalanobis uzaklığı değerlendirilmiş ve 0,001 anlamlllıkta belirlenen uzaklığ aşan toplamda 27 gözlem, veri setinden çıkartılmıştır (Arifin, 2015). Kalan 493 gözlem ile veri setinin hem tek değişkenli normalliği hem de çok değişkenli normalliği sağladığı sonucuna ulaşılmıştır.

\section{Katılımcılara Yönelik Bulgular}

Çalışma katılımcılarının \%44,4'ü kadın ( $n=219)$ ve \%55,6'sı erkektir ( $n=274)$. Katılımcıların yaşları 22 ve 60 arasında değişmekte ve yaş ortalamaları 30,33 (SS = 8,40)'tür. Yaş gruplarına bakıldığında, \%54,6'sı 22-29 yaş (n = 269), $\% 30,6$ 's 30-39 yaş $(n=151), \% 11,4^{\prime} \ddot{u}$ 40-49 yaş $(n=56)$ ve $\% 3,4^{\prime}$ ü 50 yaş ve üstünden $(\mathrm{n}=17)$ oluşmaktadır. Eğitim durumu dağılımlarına bakıldığında ise $\% 7,7^{\prime}$ sinin ilkokul veya ortaokul mezunu $(\mathrm{n}=38), \% 16,4^{\prime}$ ünün lise mezunu $(\mathrm{n}=81), \% 53,8^{\prime} \mathrm{i}$ lisans mezunu $(\mathrm{n}=265)$ ve $\% 22,1^{\prime} \mathrm{i}(\mathrm{n}=109)$ lisansüstü 
mezunu olduğu görülmektedir. Katılımcıların siyasi konularda duygu ve düşüncelerini paylaşmak ve/veya fikir edinmek için kullandıkları sosyal medya platformları Tablo 1'de gösterilmiştir.

Tablo 1. Siyasi konularda duygu ve düşünceleri paylaşmak ve/veya fikir edinmek için kullanilan sosyal medya platformlarn

\begin{tabular}{|c|c|c|c|c|c|c|}
\hline \multirow{3}{*}{$\begin{array}{l}\text { Sosyal Medya } \\
\text { Platformları }\end{array}$} & \multicolumn{4}{|c|}{ Siyasal ifade amaçlı } & \multirow{2}{*}{\multicolumn{2}{|c|}{ Toplam }} \\
\hline & \multicolumn{2}{|c|}{ Kullanırım } & \multicolumn{2}{|c|}{ Kullanmam } & & \\
\hline & $n$ & $\%$ & $n$ & $\%$ & $n$ & $\%$ \\
\hline YouTube & 268 & 56,4 & 225 & 45,6 & 493 & 100,0 \\
\hline Facebook & 228 & 46,2 & 265 & 53,8 & 493 & 100,0 \\
\hline Instagram & 262 & 53,1 & 231 & 46,9 & 493 & 100,0 \\
\hline Twitter & 222 & 45,0 & 271 & 55,0 & 493 & 100,0 \\
\hline Whatsapp & 322 & 65,3 & 171 & 34,7 & 493 & 100,0 \\
\hline
\end{tabular}

Tablo 1'deki bulgulara göre, katilımcılar siyasi konularda duygu ve düşünceleri paylaşmak ve/veya fikir edinmek için en çok Whatsapp platformunu kullanırlarken $(\% 65,3)$ en az Twitter platformunu kullanmaktadır $(\% 45,0)$.

\section{Çalışmada Kullanılan Ölçeklere Yönelik Bulgular}

Çalışmada kullanılan siyasal ifade amaçlı sosyal medya kullanımı (a), siyasal katılım (b) ve siyasal ilgi (c) ölçeklerinin bu araştırma örnekleminde faktörsel olarak nasıl dağılım gösterdiklerini görebilmek amacıyla açımlayıcı faktör analizi (AFA) gerçekleştirilmiştir (temel bileşenler analizi/varimax). Yapılan AFA'lar neticesinde KMO ve Barlett Küresellik Testi sonuçlarının sırasıyla iyi ve anlamlı çıktığı görülmüştür ( $\mathrm{a}$ için $\mathrm{KMO}=0,89, p<0,001$; $\mathrm{b}$ için $\mathrm{KMO}=0,85$, $p<0,001$; c için $\mathrm{KMO}=0,70, p<0,001)$. Söz konusu üç ölçeğin tek faktörlü yap1lara sahip oldukları belirlenmiştir. Ölçeklerin açıklanan varyansları ile öz değerlerinin yeterli (a için \%56 ve 3,95; b için \%53 ve 4,23 ; c için $\% 82$ ve 2,46 ) ve ölçeklere yönelik faktör yüklerinin (a için $0,60-0,86$; b için $0,62-0,81$; c için 0,86 $0,94)$ literatürce önerilen 0,50 sınır değerinin üzerinde olduğu tespit edilmiştir (Hair vd., 2014, s.102). 
Tablo 2. Ölçeklere yönelik yapılan AFA ve güvenirlik analizi sonuçları ile betimsel istatistikler

\begin{tabular}{|c|c|c|c|c|c|}
\hline Ölçek ve Madde & $\bar{x}$ & sS & FY & $\begin{array}{l}\text { ATV } \\
\text { (ÖD) }\end{array}$ & CA \\
\hline Siyasal ifade amaçlı sosyal medya kullanımı & 2,11 & 0,88 & - & \multirow{8}{*}{$\begin{array}{l}\% 56 \\
(3,95)\end{array}$} & \multirow{8}{*}{0,86} \\
\hline $\begin{array}{l}\text { Siyasi içerikli paylaşımları görüntüler, beğenir ve/veya } \\
\text { yorum yaparım }\end{array}$ & 2,34 & 1,18 & 0,86 & & \\
\hline $\begin{array}{l}\text { Siyasi konularla ilgili düşünce ve tepkilerimi paylaşı- } \\
\text { rım (aday/parti seçim vb.) }\end{array}$ & 2,18 & 1,18 & 0,85 & & \\
\hline $\begin{array}{l}\text { Başkalarının ürettiği siyasi içerikleri (reklam, haber, } \\
\text { metin, ses, video, foto vb.) yeniden paylaşırım }\end{array}$ & 1,92 & 1,08 & 0,82 & & \\
\hline $\begin{array}{l}\text { Toplumsal hareketler ve eylemleri sosyal medya üze- } \\
\text { rinden destekler veya tepki gösteririm }\end{array}$ & 2,33 & 1,28 & 0,75 & & \\
\hline $\begin{array}{l}\text { Siyasi konularda kendim içerik üretir ve paylaşırım } \\
\text { (metin, ses, video, foto vb.) }\end{array}$ & 1,75 & 1,02 & 0,71 & & \\
\hline İnsanları oy tercihleriyle ilgili ikna etmeye çalışırım & 1,80 & 1,16 & 0,62 & & \\
\hline $\begin{array}{l}\text { Siyasi parti ve adayların sosyal medya hesaplarını takip } \\
\text { ederim }\end{array}$ & 2,49 & 1,42 & 0,60 & & \\
\hline Siyasal katılım & 2,20 & 0,89 & - & \multirow{9}{*}{$\begin{array}{c}\% 53 \\
(4,23)\end{array}$} & \multirow{9}{*}{0,87} \\
\hline Bir parti ya da aday için gönüllü olarak çalışırım & 1,66 & 1,13 & 0,81 & & \\
\hline $\begin{array}{l}\text { Başkalarını bir parti ya da adaya oy vermeleri için ikna } \\
\text { etmeye çalışırım }\end{array}$ & 1,88 & 1,25 & 0,79 & & \\
\hline $\begin{array}{l}\text { Ailem/arkadaşlarım/çevremdeki insanlarla siyasi konu- } \\
\text { larla ilgili konuşurum }\end{array}$ & 3,03 & 1,30 & 0,76 & & \\
\hline Siyasi konularda başkalanyla tartışırım & 2,35 & 1,31 & 0,76 & & \\
\hline Siyasi parti ya da adayların mitinglerine katılırım & 1,80 & 1,14 & 0,73 & & \\
\hline $\begin{array}{l}\text { Hükümet veya yerel yöneticilerle, fikirlerimi söylemek } \\
\text { veya çözüm önerileri sunmak için iletişime geçerim }\end{array}$ & 1,85 & 1,14 & 0,68 & & \\
\hline Sivil toplum kuruluşlarında görev alırım & 1,95 & 1,23 & 0,65 & & \\
\hline Siyasi içerikli açıkoturum ve programları izlerim & 3,09 & 1,35 & 0,62 & & \\
\hline Siyasal ilgi & 3,17 & 1,21 & - & \multirow{4}{*}{$\begin{array}{l}\% 82 \\
(2,46)\end{array}$} & \multirow{4}{*}{0,89} \\
\hline $\begin{array}{l}\text { Muhalefetin meselelere (sosyal, siyasi ekonomik vb.) } \\
\text { yaklaşımları }\end{array}$ & 3,25 & 1,34 & 0,94 & & \\
\hline $\begin{array}{l}\text { Devlet ve Hükümet işleri (hükümetin, siyasi, sosyal, } \\
\text { ekonomik, askeri vb. politik yaklaşımları ve icraatlan) }\end{array}$ & 3,29 & 1,36 & 0,92 & & \\
\hline Yasama/Meclis (TBMM) çalışmalarıyla & 2,97 & 1,31 & 0,86 & & \\
\hline
\end{tabular}

Elde edilen bu sonuçlara istinaden ilgili ölçeklerin güvenilir olup olmadıkları Cronbach's Alpha güvenirlik katsayısı kullanılarak kontrol edilmiş (a için $\alpha=0,86$; $\mathrm{b}$ için $\alpha=0,87$; c için $\alpha=0,89$ ) ve hepsinin güvenilir olduğu sonucuna ulaşılmıştır (Kalaycı, 2017, s.405). Elde edilen bu sonuçlar Tablo 2'de gösterilmiştir. Öte yandan, ölçeklerin aritmetik ortalamalarına bakıldığında en yüksek aritmetik ortalamaya sahip ölçeğin siyasal ilgi olduğu $(\bar{x}=3,17$; SS 
$=1,21)$, bunu siyasal katılım $(\bar{x}=2,20 ; S S=0,89)$ ve siyasal ifade amaçlı sosyal medya kullanımı $(\bar{x}=2,11$; SS $=0,88)$ izlediği görülmektedir. Buradan hareketle katılımcıların siyasal ilgi düzeyinin yüksek olduğu söylenebilirken siyasal katılım ve siyasal ifade amaçlı sosyal medya kullanımı düzeylerinin genel olarak düşük olduğu ifade edilebilir. Bu bulgular Tablo 2'de gösterilmiştir.

\section{Kümeleme Analizine İlişkin Bulgular}

Siyasal ifade amaçlı sosyal medya kullanımı açısından katılımcları gruplandırabilmek için iki adımlı bir kümeleme analizine gidilmiştir. İlk adımda, kullanıma yönelik kümeleme uygulanmadan önce hiyerarşik bir kümeleme yöntemi olan Ward tekniği aracılığıyla katılımcıların siyasal ifade amaçlı sosyal medya kullanım ortalamalarından faydalanılarak kullanım örüntüleri değerlendirilmiştir (Hair vd., 2014, s.442). İncelenen yığışım tablosu neticesinde üç gruptan oluşan bir kümenin kullanılabileceği anlaşılmıştır.

Yaklaşımın ikinci adımında hiyerarşik olmayan bir kümeleme yöntemi olan k-ortalamalar tekniği vasitasıyla birinci adımda uygun görülen üç gruplu kümenin güvenirliği test edilmiştir. Bu analiz sonucunda hem Ward hem de k-ortalamalar tekniği için elde edilen ortalamaların birbirlerine yakın düzeylerde olduğu tespit edilmiştir. Dolayısıyla siyasal ifade amaçlı sosyal medya kullanımı a) düşük düzeyde kullananlar, b) orta düzeyde kullananlar ve c) yüksek düzeyde kullananlar olarak üç gruptan oluşan bir kümeleme yapılmıştır. Elde edilen kümelere yönelik betimsel bilgiler Tablo 3 'te paylaşılmıştır.

Tablo 3. Siyasal ifade amaçh sosyal medya kullanımına yönelik yapılan kümeleme analizi

\begin{tabular}{|c|c|c|c|c|c|c|}
\hline \multirow{3}{*}{ Maddeler } & \multicolumn{6}{|c|}{ Kümeler } \\
\hline & \multicolumn{2}{|c|}{$\begin{array}{c}\text { Düşük } \\
(n=217 ; \% 44,0) \\
\end{array}$} & \multicolumn{2}{|c|}{$\begin{array}{c}\text { Orta } \\
(n=186 ; \% 37,7) \\
\end{array}$} & \multicolumn{2}{|c|}{$\begin{array}{c}\text { Yüksek } \\
(n=90 ; \% 18,3)\end{array}$} \\
\hline & $\bar{x}$ & SS & $\bar{x}$ & SS & $\bar{x}$ & SS \\
\hline $\begin{array}{l}\text { Siyasi konularda kendim içerik üretir ve } \\
\text { paylaşırım (metin, ses, video, foto vb.) }\end{array}$ & 1,14 & 0,44 & 1,88 & 0,87 & 2,97 & 1,14 \\
\hline $\begin{array}{l}\text { Siyasi içerikli paylaşımları görüntüler, be- } \\
\text { ğenir ve/veya yorum yaparım }\end{array}$ & 1,41 & 0,62 & 2,65 & 0,73 & 3,94 & 0,87 \\
\hline $\begin{array}{l}\text { Başkalarının ürettiği siyasi içerikleri (rek- } \\
\text { lam, haber, metin, ses, video, foto vb.) yeni- } \\
\text { den paylaşırım }\end{array}$ & 1,19 & 0,46 & 2,03 & 0,81 & 3,43 & 0,96 \\
\hline
\end{tabular}




\begin{tabular}{lcccccc}
\hline $\begin{array}{l}\text { Siyasi konularla ilgili düşünce ve tepkile- } \\
\text { rimi paylaşırım (aday/parti seçim vb.) }\end{array}$ & 1,32 & 0,58 & 2,38 & 0,83 & 3,83 & 0,89 \\
\hline $\begin{array}{l}\text { Toplumsal hareketler ve eylemleri sosyal } \\
\text { medya üzerinden destekler veya tepki gös- } \\
\text { teririm }\end{array}$ & 1,35 & 0,66 & 2,77 & 1,04 & 3,77 & 0,98 \\
\hline $\begin{array}{l}\text { İnsanları oy tercihleriyle ilgili ikna etmeye } \\
\text { çalışırm }\end{array}$ & 1,28 & 0,67 & 1,78 & 0,98 & 3,12 & 1,37 \\
\hline $\begin{array}{l}\text { Siyasi parti ve adayların sosyal medya he- } \\
\text { sapların takip ederim }\end{array}$ & 1,73 & 1,12 & 2,66 & 1,28 & 4,00 & 0,96 \\
\hline Aritmetik Ortalama & 1,35 & 0,65 & 2,31 & 0,93 & 3,58 & 1,02 \\
\hline
\end{tabular}

(1 - Hiçbir Zaman; 5 - Her Zaman).

Siyasal ifade amaçlı sosyal medyayı düşük düzeyde kullananların siyasi parti ve adayların sosyal medya hesaplarını daha çok takip ettiği görülürken siyasi konularda içerik üretip paylaşmayı neredeyse hiç yapmadıkları söylenebilir. Orta düzeyde kullananların toplumsal hareketler ve eylemleri sosyal medya üzerinden desteklemeyi ve tepki göstermeyi daha çok yaptıkları belirtilebilirken daha az olarak insanları oy tercihleriyle ilgili ikna etmeye çalıştıkları ifade edilebilir. Yüksek düzeyde kullananların ise neredeyse bütün maddeleri çoğunlukla yaptıkları söylenebilirken özelde daha çok siyasi parti ve adayların sosyal medya hesaplarını takip ettikleri; siyasi konularda içerik üretip paylaşmayı ise nispeten daha az yaptıkları değerlendirilebilir.

\section{Siyasal Iffade Amaçlı Sosyal Medya Kullanım Düzeyi Açısından Demografik Özelliklerin İncelenmesi}

Siyasal ifade amaçlı sosyal medya kullanım düzeyi ile cinsiyet, eğitim durumu ve siyasi konularda duygu ve düşünceleri paylaşmak ve/veya fikir edinmek için kullanılan sosyal medya platformları arasında anlamlı bir ilişkinin/bağın olup olmadığını tespit edebilmek amacıyla ki-kare bağımsızlık testi uygulanmıştır. Elde edilen sonuçlar Tablo 4 'te gösterilmiştir. Bu sonuçlara göre kullanım düzeyi ile cinsiyet, yaş ve eğitim durumu arasında anlamlı bir ilişki tespit edilememiştir $(p>0,05)$. Bununla birlikte, siyasi konularda duygu ve düşünceleri paylaşmak ve/veya fikir edinmek için kullanılan sosyal medya platformlarından YouTube $(p>0,05)$ dişında Facebook $\left(x^{2}=24,70 ; \mathrm{df}=\right.$ $2 ; p<0,001)$, Instagram $\left(x^{2}=11,07 ; \mathrm{df}=2 ; p<0,01\right)$, Twitter $\left(x^{2}=44,87 ; \mathrm{df}=2\right.$; $p<0,001)$ ve Whatsapp $\left(x^{2}=18,65 ; \mathrm{df}=2 ; p<0,001\right)$ platformlariyla anlamlı bir ilişkisi/bağı olduğu sonucuna ulaşılmıştır. 
Tespit edilen bu anlamlı ilişkiler/bağlar, kullanım düzeyi düşük olan katılımcların Facebook $(\% 64,1)$, Instagram $(\% 54,4)$ ve Twitter $(\% 70,0)$ platformlarını çoğunlukla kullanmadıklarını gösterirken Whatsapp platformunu $(\% 55,8)$ ağırlıklı olarak kullandıklarını göstermektedir. Kullanım düzeyi orta olan katılımcılar çoğunlukla Instagram $(\% 55,9)$ ve Whatsapp $(\% 69,4)$ platformunu kullanırken Twitter $(\% 50,5)$ platformunu nispeten tercih etmektedir. Bununla birlikte, bu katılımcılar Facebook platformunu çoğunlukla kullanmamaktadır $(\% 51,6)$. Kullanım düzeyi yüksek olan katılımclar ise Facebook $(\% 66,7)$, Instagram $(\% 65,6)$, Twitter $(\% 70,0)$ ve Whatsapp $(\% 80,0)$ platformlarını ağırlıkla kullanmaktadır. Öte yandan, cinsiyet, yaş, eğitim durumu ve YouTube kullanımı açısından anlamlı bir iliş̧i/bağ tespit edilmemesi katılımcıların cinsiyet, yaş, eğitim durumu ve YouTube platformu fark etmeksizin siyasal ifade amaçlı sosyal medyayı benzer seviyelerde kullandıklarını gösterir niteliktedir.

Tablo 4. Siyasal ifade amaçlı sosyal medya kullanım düzeyi açısından demografik özelliklerin incelenmesi

\begin{tabular}{|c|c|c|c|c|c|c|c|c|}
\hline \multicolumn{2}{|c|}{ Demografik Değişkenler } & \multicolumn{6}{|c|}{ Kullanım Düzeyi } & \multirow{3}{*}{$x^{2}(\mathrm{df})$} \\
\hline \multirow{2}{*}{ Değişken } & \multirow{2}{*}{ Grup } & \multicolumn{2}{|c|}{ Düşük } & \multicolumn{2}{|c|}{ Orta } & \multicolumn{2}{|c|}{ Yüksek } & \\
\hline & & $n$ & $\%$ & $n$ & $\%$ & $n$ & $\%$ & \\
\hline \multirow{3}{*}{ Cinsiyet } & Kadın & 103 & 47,5 & 83 & 44,6 & 33 & 36,7 & \multirow{3}{*}{$3,01(2)$} \\
\hline & Erkek & 114 & 52,5 & 103 & 55,4 & 57 & 63,3 & \\
\hline & Toplam & 217 & 100,0 & 186 & 100,0 & 90 & 100,0 & \\
\hline \multirow{5}{*}{ Yaş } & $22-29$ yaş & 121 & 55,8 & 97 & 52,2 & 51 & 56,7 & \multirow{5}{*}{$3,13(6)$} \\
\hline & 30-39 yaş & 66 & 30,4 & 61 & 32,8 & 24 & 26,7 & \\
\hline & $40-49$ yaş & 21 & 9,7 & 22 & 11,8 & 13 & 14,4 & \\
\hline & 50 yaş ve üstü & 9 & 4,1 & 6 & 3,2 & 2 & 2,2 & \\
\hline & Toplam & 217 & 100,0 & 186 & 100,0 & 90 & 100,0 & \\
\hline \multirow{5}{*}{ Eğitim Durumu } & İlkokul/Ortaokul & 16 & 7,4 & 17 & 9,1 & 5 & 5,6 & \multirow{5}{*}{$4,58(6)$} \\
\hline & Lise & 29 & 13,4 & 34 & 18,3 & 18 & 20,0 & \\
\hline & Lisans & 121 & 55,8 & 94 & 50,6 & 50 & 55,5 & \\
\hline & Lisansüstü & 51 & 23,5 & 41 & 22,0 & 17 & 18,9 & \\
\hline & Toplam & 217 & 100,0 & 186 & 100,0 & 90 & 100,0 & \\
\hline \multirow{3}{*}{ YouTube } & Kullanırım & 107 & 49,3 & 106 & 57,0 & 55 & 61,1 & \multirow{3}{*}{$4,40(2)$} \\
\hline & Kullanmam & 110 & 50,7 & 80 & 43,0 & 35 & 38,9 & \\
\hline & Toplam & 217 & 100,0 & 186 & 100,0 & 90 & 100,0 & \\
\hline \multirow{3}{*}{ Facebook } & Kullanırım & 78 & 35,9 & 90 & 48,4 & 90 & 66,7 & \multirow{3}{*}{$\begin{array}{c}24,70^{* * *} \\
(2)\end{array}$} \\
\hline & Kullanmam & 139 & 64,1 & 96 & 51,6 & 30 & 33,3 & \\
\hline & Toplam & 217 & 100,0 & 186 & 100,0 & 90 & 100,0 & \\
\hline \multirow{3}{*}{ Instagram } & Kullanırım & 99 & 45,6 & 104 & 55,9 & 59 & 65,6 & \multirow{3}{*}{$11,07^{* *}(2)$} \\
\hline & Kullanmam & 118 & 54,4 & 82 & 44,1 & 31 & 34,4 & \\
\hline & Toplam & 217 & 100,0 & 186 & 100,0 & 90 & 100,0 & \\
\hline Twitter & Kullanırım & 65 & 30,0 & 94 & 50,5 & 63 & 70,0 & \\
\hline
\end{tabular}




\begin{tabular}{llcccccccc}
\hline & Kullanmam & 152 & 70,0 & 92 & 49,5 & 27 & 30,0 & $44,87^{* * *}$ \\
\cline { 2 - 8 } & Toplam & 217 & 100,0 & 186 & 100,0 & 90 & 100,0 & $(2)$ \\
\hline \multirow{3}{*}{ Whatsapp } & Kullanirm & 121 & 55,8 & 129 & 69,4 & 72 & 80,0 & \multirow{2}{*}{$18,65^{* * *}$} \\
& Kullanmam & 96 & 44,2 & 57 & 30,6 & 18 & 20,0 & \multirow{2}{*}{$(2)$} \\
\cline { 2 - 7 } & Toplam & 217 & 100,0 & 186 & 100,0 & 90 & 100,0 & \\
\hline
\end{tabular}

${ }^{* * *} \mathrm{p}<0,001 ; * * \mathrm{p}<0,01$.

Siyasal İfade Amaçlı Sosyal Medya Kullanım Düzeyi Açısından Siyasal Katılım ve Siyasal İlginin İncelenmesi

Siyasal ifade amaçlı sosyal medya kullanım düzeyi açısından siyasal katılım ve siyasal ilginin anlamlı bir şekilde farklılaşıp farklılaşmadığını tespit edebilmek amacıyla tek yönlü varyans analizi (ANOVA) kullanılmıştır. Analiz sonuçlarında Levene istatistiği, hem siyasal katılım $(F=15,325 ; p<0,001)$ hem de siyasal ilgi $(F=10,045 ; p<0,001)$ açısından kullanım düzeyi gruplarının homojen dağılmadığını gösterdiğinden dolayı analizin yorumlanması aşamasında Brown-Forsythe istatistiği kullanılmıştır (Pallant, 2011, s.253). Elde edilen sonuçlar Tablo 5 'te gösterilmiştir.

Tablo 5. Siyasal ifade amaçl sosyal medya kullanım düzeyi açısından siyasal katılım ve siyasal ilginin incelenmesi

\begin{tabular}{|c|c|c|c|c|c|c|}
\hline Değişken & Grup & $n$ & $\bar{x}$ & SS & $F$ & $p$ \\
\hline \multirow{3}{*}{ Siyasal Katılım } & Düşük & 217 & 1,67 & 0,54 & \multirow{3}{*}{171,196} & \multirow{3}{*}{$<0,00$} \\
\hline & Orta & 186 & 2,27 & 0,67 & & \\
\hline & Yüksek & 90 & 3,34 & 0,86 & & \\
\hline \multirow{3}{*}{ Siyasal İlgi } & Düşük & 217 & 2,78 & 1,26 & \multirow{3}{*}{33,696} & \multirow{3}{*}{$<0,001$} \\
\hline & Orta & 186 & 3,28 & 1,08 & & \\
\hline & Yüksek & 90 & 3,88 & 0,96 & & \\
\hline
\end{tabular}

(1 - Hiç; 5-Her Zaman).

Tablo 5'te siyasal ifade amaçlı sosyal medya kullanım düzeyi açısından hem siyasal katılım $(F=171,196 ; p<0,001)$ hem de siyasal ilgi $(F=33,696$; $p<0,001)$ anlamlı bir şekilde farklılaşmaktadır. Elde edilen bu farklılığın hangi düzey grupları arasında olduğunu belirleyebilmek için Tamhane testi gerçekleştirilmiştir (Kalaycı, 2017, s.15). Test sonuçlarına göre siyasal katılımda kullanım açısından düşük düzeye sahip katılımclar ile orta düzeye ( $\mathrm{md}=-0,59$; $p<0,001$ ) ve yüksek düzeye sahip ( $m d=-1,67 ; p<0,001$ ) katılımcllar arasında anlamlı bir farklılık vardır. Orta düzeye sahip katılımclar ile yüksek düzeye sahip katılımclar arasında da anlamlı bir farklılık vardır ( $\mathrm{md}=-1,07 ; p<0,001$ ). 
Siyasal ilgi bağlamında kullanım açısından düşük düzeye sahip katılımc1lar ile orta düzeye $(m d=-0,49 ; p<0,001)$ ve yüksek düzeye sahip ( $m d=-1,09$; $p<0,001)$ katılımcılar arasında anlamlı bir farklılık söz konusudur. Ayrıca, orta düzeye sahip katılımcılar ile yüksek düzeye sahip katılımcılar arasında da anlamlı bir farklılık olduğu görülmektedir ( $\mathrm{md}=-0,60 ; p<0,001)$. Elde edilen sonuçlar, siyasal ifade amaçlı sosyal medya kullanım düzeyi yüksek olan katılımcıların siyasal katılım ve siyasal ilgiye daha yüksek seviyelerde sahip olduğunu göstermektedir.

Kullanım düzeyi orta olan katılımclların siyasal katılım göstermesi nispeten daha düşük kalırken, siyasal ilgilerinin kullanım düzeyi düşük olanlara göre daha fazla olduğu görülmektedir. Öte yandan, kullanım düzeyi düşük olan katılımclarda hem siyasal katılımın hem de siyasal ilginin, kullanım düzeyi orta ve yüksek olanlara göre daha alt seviyelerde kaldığı dikkat çekmektedir (Şekil 1).

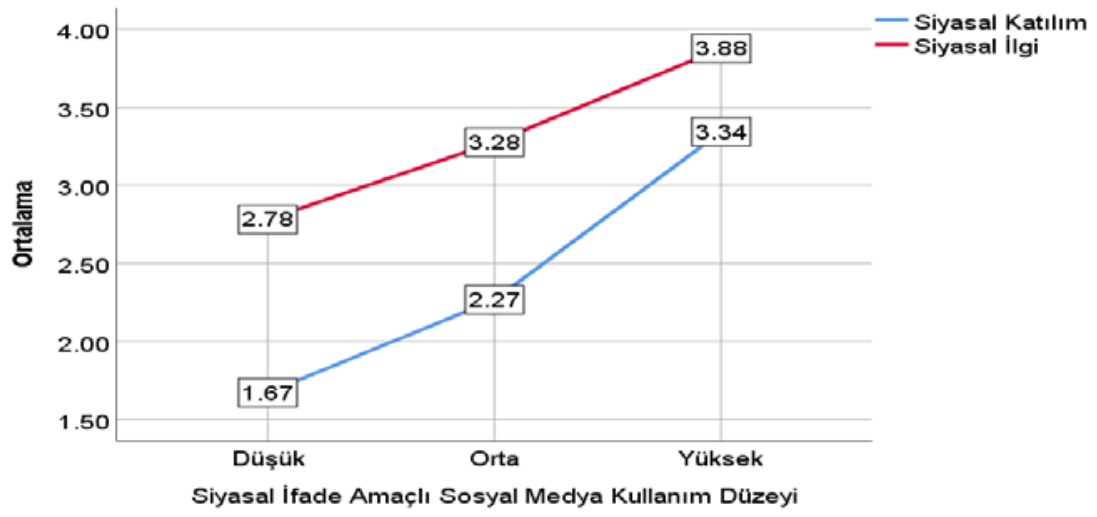

Şekil 1. Kullanım düzeyi açısından siyasal katılım ve siyasal ilginin incelenmesi

\section{Platformlar Açısından Siyasal Katılım ve Siyasal İlginin İncelenmesi}

Siyasi konularda duygu ve düşünceleri paylaşmak ve/veya fikir edinmek için kullanılan sosyal medya platformları açısından siyasal katılım ve siyasal ilginin anlamlı bir şekilde farklılaşıp farklılaşmadığını belirleyebilmek amacıyla bağımsız örneklemler t-test yapılmıştır. Analiz sonuçları Tablo 6'da paylaşılmiştrr. 
Siyasal İfade Amaçlı Sosyal Medya Kullanım Düzeyinin Siyasal İlgi ve Katılım Üzerinde Rolü: Sosyal Medya Platformları Bağlamında Bir Saha Araştırması

Tablo 6. Platformlar açısından siyasal katılım ve siyasal ilgi değişkenlerinin incelenmesi

\begin{tabular}{|c|c|c|c|c|c|c|c|c|}
\hline Platform & Yap1 & Grup & $n$ & $\overline{\bar{x}}$ & SS & $t$ & df & $p$ \\
\hline \multirow{4}{*}{ YouTube } & Siyasal & Kullanırım & 268 & 2,26 & 0,90 & \multirow{2}{*}{1,61} & \multirow{2}{*}{491} & \multirow{2}{*}{0,11} \\
\hline & Katılım & Kullanmam & 225 & 2,13 & 0,87 & & & \\
\hline & \multirow{2}{*}{$\begin{array}{l}\text { Siyasal } \\
\text { İlgi }\end{array}$} & Kullanirım & 268 & 3,26 & 1,21 & \multirow{2}{*}{1,76} & \multirow{2}{*}{91} & \multirow{2}{*}{0,08} \\
\hline & & Kullanmam & 225 & 3,06 & 1,21 & & & \\
\hline \multirow{4}{*}{ Facebook } & \multirow{2}{*}{$\begin{array}{l}\text { Siyasal } \\
\text { Katılım }\end{array}$} & Kullanırım & 228 & 2,43 & 1,00 & \multirow{2}{*}{5,42} & \multirow{2}{*}{412,7} & \multirow{2}{*}{$<0,001$} \\
\hline & & Kullanmam & 265 & 2,00 & 0,74 & & & \\
\hline & \multirow{2}{*}{$\begin{array}{l}\text { Siyasal } \\
\text { İlgi } \\
\end{array}$} & Kullanırım & 228 & 3,44 & 1,19 & \multirow{2}{*}{4,66} & \multirow{2}{*}{491} & \multirow{2}{*}{$<0,001$} \\
\hline & & Kullanmam & 265 & 2,94 & 1,18 & & & \\
\hline \multirow{4}{*}{$\begin{array}{l}\text { Instag- } \\
\text { ram }\end{array}$} & \multirow{2}{*}{$\begin{array}{l}\text { Siyasal } \\
\text { Katılım }\end{array}$} & Kullanırım & 262 & 2,23 & 0,95 & \multirow{2}{*}{0,89} & \multirow{2}{*}{491} & \multirow{2}{*}{0,40} \\
\hline & & Kullanmam & 231 & 2,16 & 0,82 & & & \\
\hline & \multirow{2}{*}{$\begin{array}{l}\text { Siyasal } \\
\text { İlgi }\end{array}$} & Kullanırım & 262 & 3,18 & 1,23 & \multirow{2}{*}{0,29} & \multirow{2}{*}{491} & \multirow{2}{*}{0,77} \\
\hline & & Kullanmam & 231 & 3,15 & 1,19 & & & \\
\hline \multirow{4}{*}{ Twitter } & \multirow{2}{*}{$\begin{array}{l}\text { Siyasal } \\
\text { Katılım }\end{array}$} & Kullanirım & 222 & 2,46 & 0,95 & \multirow{2}{*}{5,92} & \multirow{2}{*}{426,9} & \multirow{2}{*}{$<0,001$} \\
\hline & & Kullanmam & 271 & 1,99 & 0,78 & & & \\
\hline & \multirow{2}{*}{$\begin{array}{l}\text { Siyasal } \\
\text { İlgi } \\
\end{array}$} & Kullanırım & 222 & 3,48 & 1,14 & \multirow{2}{*}{5,24} & \multirow{2}{*}{491} & $<0001$ \\
\hline & & Kullanmam & 271 & 2,92 & 1,21 & & & $<0,001$ \\
\hline & Siyasal & Kullanırım & 322 & 2,30 & 0,92 & 373 & 3942 & $<0001$ \\
\hline What- & Katılım & Kullanmam & 171 & 2,01 & 0,79 & 3,13 & 394,2 & $<0,001$ \\
\hline sapp & Siyasal & Kullanırım & 322 & 3,25 & 1,18 & 213 & 491 & $003 *$ \\
\hline & İlgi & Kullanmam & 171 & 3,01 & 1,25 & 2,10 & & 0,00 \\
\hline
\end{tabular}

${ }^{*} \mathrm{p}<0,05$.

Tablo 6' da görüleceği üzere Facebook açısından siyasal katılım $(t=5,42$; $\mathrm{df}$ $=412,7 ; p<0,001)$, siyasal ilgi $(t=4,66 ; \mathrm{df}=491 ; p<0,001)$; Twitter açısından siyasal katılım $(t=5,92 ; \mathrm{df}=426,9 ; p<0,001)$, siyasal ilgi $(t=5,24 ; \mathrm{df}=491 ; p<0,001)$ ve Whatsapp açısından siyasal katılım $(t=3,73 ; \mathrm{df}=394,2 ; p<0,001)$ ve siyasal ilgi $(t=2,13 ; \mathrm{df}=491 ; p<0,05)$ anlamlı bir şekilde farklılaşmaktadır (Şekil 2).

YouTube ve Instagram açısından ise siyasal katılım ve siyasal ilgi anlamlı bir şekilde farklılaşmamaktadır ( $p>0,05)$. Bu bulgular, siyasi konularda duygu ve düşünceleri paylaşmak ve/veya fikir edinmek için kullanılan Facebook, Twitter ve Whatsapp platformlarında daha yüksek siyasal katılım ve siyasal ilgi seviyelerinin olduğunu göstermektedir. Bununla birlikte, YouTube ve Instagram platformlarında kullanım durumu fark etmeksizin benzer seviyelerde siyasal katılım ve siyasal ilginin olduğu dikkat çekmektedir. 


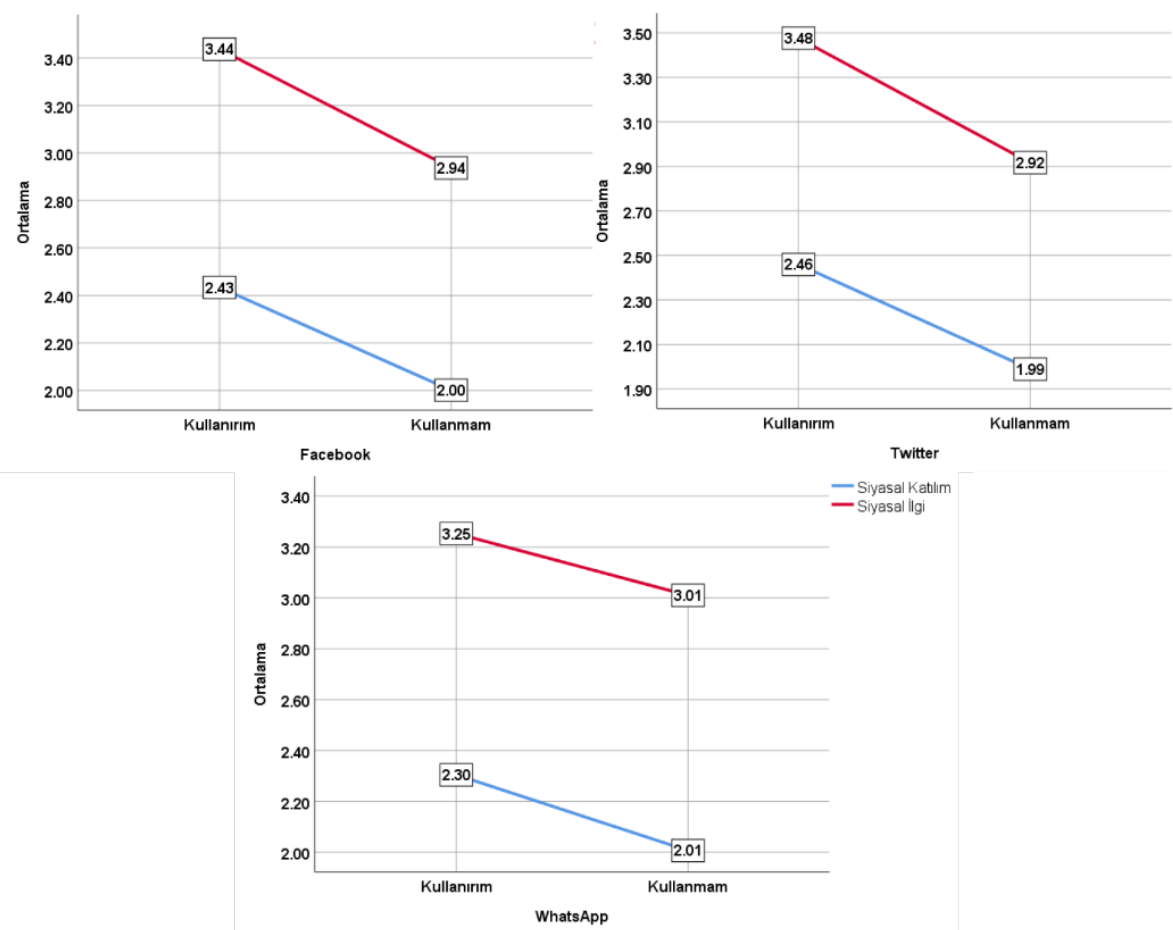

Şekil 2. Platformlar açısından siyasal katılım ve siyasal ilgi değişkenlerinin incelenmesi

\section{Tartışma ve Sonuç}

Bu çalışmada Türkiye'deki sosyal medya kullanıcılarının siyasal katılımları ve siyasal ilgileri, siyasal ifade amaçlı sosyal medya kullanımları açısından incelenmek istenmiştir. Söz konusu inceleme Türkiye'de 2020 itibariyle en fazla kullanılan beş sosyal medya platformu özelinde gerçekleştirilmiştir. Siyasal ifade amaçlı sosyal medya kullanımı, kullanım düzeyine göre gruplandırılarak ilgili grupların demografik özellikler ile ilişkisine bakılmıştır. Böylelikle her bir düzeyin nasıl bir örüntü sergilediği ortaya çıkarılmaya çalışılmıştır. Ayrıca kullanıcıların siyasi konularda duygu ve düşünceleri paylaşmak ve/veya fikir edinmek için kullandıkları sosyal medya platformları açısından siyasal ilgi ve siyasal katılım da mercek altına alınarak platformlar özelinde ilgili değişkenlerin nasıl bir farklılık gösterdiği irdelenmiştir.

Genel itibariyle çalışma bulguları hem bireylerin hem de kurumsal yapıların farklı biçimlerde istifade ettiği sosyal medya platformlarının diğer alanlarda olduğu gibi siyasal alanda da etki rolü göz ardı edilemez kullanım alanı 
olduğunu göstermektedir. Özellikle siyasi konularda düşünceleri paylaşmak ya da fikir edinmek için Whatsapp platformunun daha çok kullanılması, ilgili platformun siyasal ifade açısından önemli bir alan oluşturduğunu gösterir niteliktedir. Whatsapp'ın sesli ve görüntülü görüşme, konum gönderme/alma, metin, anında fotoğraf ve video paylaşım gibi niteliklere sahip olması, bireylerin daha zahmetsiz ve hızlı bir şekilde duygu ve düşüncelerini ifade edebilmelerini sağlamaktadır (Ünal, 2019, s. 34). Öte yandan, diğer sosyal medya platformları benzer nitelikleri kullanıcılarına sunabilse de bu daha zaman alıcı ve zahmetli bir şekilde gerçekleşebilmektedir. Whatsapp ise ilgili iletinin kime/kimlere iletileceğini daha spesifik bir şekilde belirlemeye imkân sağlamaktadır. Böylelikle kim/kimler tarafından alınacağının önceden bilinmesi ve bu doğrultuda tasarlanması, bireylerin diğer konularda olduğu gibi siyasal konularda da düşüncelerini daha rahat ve özgür bir şekilde aktarmalarına olanak tanımaktadır (Yaşar, 2020, s. 172-173).

Çalışmada siyasal ilgi düzeyinin genel anlamda yüksek olduğu belirlenirken siyasal katılım ve siyasal ifade amaçlı sosyal medya kullanımının nispeten düşük olduğu tespit edilmiştir. Sosyal medya platformlarında yalnızca seçim dönemlerinde değil, olağan dönemlerde de gerçekleşen siyasal gelişmeler ve değişimler doğrultusunda bireylerin tutum ve kanaatlerinin değişebileceği, bundan dolayı da siyasal ilgilerinin yüksek olabileceği düşünülmektedir. Bununla birlikte, seçim dönemleri dışında siyaset çok ön planda olmadığından hem siyasal katılımın hem de siyasal ifade amaçlı sosyal medya kullanımının daha az olduğu değerlendirilebilir. Zira seçim dönemleri, mecliste ve hükümette yaşanan gelişmeler başta olmak üzere siyaseti ilgilendiren konularda bireylerin günlük hayattaki gündemini etkileyebildiği gibi sosyal medyadaki gündemini de etkileyebilmektedir. Özellikle bu zamanlarda bireylerin siyasal katılımı ve siyasal ifade amaçlı sosyal medya kullanımı daha yüksek olabileceği değerlendirilmektedir (Arklan, 2016, s.623).

Siyasal ifade amaçlı sosyal medya kullanımı düşük, orta ve yüksek düzeyde kullanım olarak üç kümeye bölünmüştür. Kullanımı düşük düzeyde olanlar, siyasi parti ve adayların sosyal medya hesaplarını daha çok takip ederken siyasi konularda içerik üretmeyi ve paylaşmayı neredeyse hiç yapmamaktadır. Orta düzeyde kullananlar, toplumsal hareketler ve eylemleri sosyal medya üzerinden desteklemeyi veya onlara tepki göstermeyi daha çok tercih ederken diğer bireyleri oy tercihleriyle ilgili daha az ikna etmeye çalış- 
maktadır. Yüksek düzeyde kullananlar ise çoğunlukla siyasal parti ve adayların sosyal medya hesaplarını takip ederken diğer iki grupla karşılaştırıldığında aynı zamanda siyasi konularda içeriği nispeten üretip paylaşmaktadır. Düzeylere göre farklılaşabilen bu davranışların bireyin siyasal sistemle kurmuş olduğu ilgi ve katılımla yakından alakalı olduğu düşünülmektedir. Bu çerçevede birey, siyasal olayları izlemek, takip etmek ve bilgi edinmekten siyasal eylemlerde bulunmaya, çevresini ikna etmeye, hatta adaylı̆̆a ve siyasal karar mekanizmalarında yer almaya kadar uzanan çeşitli biçim ve boyutlarda kendini gösterebilmektedir (Canbaz vd., 2019, s.2539). Öte yandan birey, siyasal içerikli paylaşımlarda bulunmaktan bazı nedenlerden ötürü çekince duyabilmektedir. Özellikle yasal yaptırımlara maruz kalmak, siyasi görüş olarak ifşa olmak, aşırı siyasi biri olarak algılanmak, farklı görüşteki arkadaşları kırmak, herkese eşit mesafede olma isteği, siyasal konuları paylaşmaya değer bulmama, sosyal çevreden dişlanma korkusu ve aile yapısına uygun olmadığı düşüncesi gibi nedenler, sosyal medya platformlarında siyasal içerikli paylaşımları üretmede ve paylaşmada engelleyici rol oynayan etmenler olarak ortaya çıabilmektedir (Arklan, 2016, s.624).

Siyasal ifade amaçlı sosyal medya kullanım düzeyleri açısından demografik özelliklerin incelenmesi sonucunda cinsiyet, yaş ve eğitim durumunun düzeyler ile anlamlı bir ilişkiye sahip olmadığı belirlenmiştir. Bireyler cinsiyetleri, yaşları ve eğitim durumları fark etmeksizin sosyal medyayı siyasal ifade amaçlı benzer seviyelerde kullanmaktadır. Bir grubun diğerinden daha az ya da diğerinden daha fazla bir kullanımı söz konusu değildir. Bu bulgu Olkun vd. (2018) tarafından yapılan çalışmanın bulgularını genişletir niteliktedir. Olkun vd. (2018, s. 997)'nin çalışmalarında siyasal karar alma sürecinde internet ve sosyal medyanın önemli bir role sahip olduğunu tespit etmiş ve erkeklerin kadınlara göre siyasal kararlarda daha fazla sosyal medyaya önem verdiğini göstermiştir. Bu çalışmada ise verilen önemin ötesinde sosyal medyanın siyasal ifade amaçı kullanımında cinsiyetin bir rolü olmadığı belirlenmiştir. Dolayısıyla bireylerin sosyal medyaya siyasal karar alma sürecinde atfettiği önem değişebilirken, siyasal ifade amaçlı kullanım söz konusu olduğunda bu durum değişmemektedir. Öte yandan Facebook, Instagram, Twitter ve Whatsapp platformlarıyla kullanım düzeyleri arasında anlamlı bir ilişki tespit edilmiştir. Bir diğer deyişle, ilgili platformda sosyal medyanın siyasal ifade amaçlı kullanım düzeyi farklılaşmaktadır. Öyle ki Whatsapp, bü- 
tün düzeyler açısından daha çok tercih edilen platform olarak ön plana çıarken bunu düzey yükseldikçe sırasıyla Instagram, Facebook ve Twitter takip etmektedir. YouTube ise her düzey için genel kullanım alanı bulan bir platform olarak görülebilir.

Siyasal katılım ve siyasal ilginin siyasal ifade amaçlı sosyal medya kullanım düzeyi açısından farklılaştığı belirlenmiştir. Kullanım düzeyi yüksek olan bireylerin siyasal katılım ve siyasal ilgi seviyelerinin de yüksek olduğu dikkat çekerken, kullanım düzeyi orta olan bireylerin ilgi ve katılımı orta düzeyde olduğu görülmüştür. Kullanım düzeyi düşük olan katılımcılarda benzer şekilde katılım ve ilgi açısından düşük seviyelerde yer almıştır. Bu durum siyasal katılım ve siyasal ilgi üzerinde siyasal ifade amaçlı sosyal medya kullanımının rolünü gösterir niteliktedir. Birey, siyasal ifade amaçlı sosyal medya kullanım düzeyini artırdığında siyasal katılım ve siyasal ilgi seviyesi de yükselebilmektedir. Ancak, siyasal katılım ve siyasal ilgiye yönelik birçok değişken söz konusu olabilmektedir ve sosyal medya kullanımını burada tek çözüm olarak sunmak oldukça iddialı görülecektir. Bununla birlikte, sonuçlar oldukça önemli ipuçları sunmakla beraber, sosyal medyanın bireysel olarak siyasal ifade amaçlı kullanımını merkeze alarak yapılacak çalışmaların siyasal katılım ve siyasal ilgiyi farklı yönleriyle özellikle birey-siyaset ilişkisini açıklamada detaylı ve özgün veriler sağlayacağı düşünülmektedir (Yaşar, 2020, s. 170).

Siyasi konularda duygu ve düşünceleri paylaşmak ve/veya fikir edinmek için kullanılan sosyal medya platformları açısından siyasal katılım ve siyasal ilginin Facebook, Twitter ve Whatsapp platformlarında farklılaşması, bu platformların siyasal iletişim açısından önemini ortaya koymaktadır. Siyasal katılımın ve siyasal ilginin en yüksek seviyede Twitter'da görülmesi, daha önceki çalışmaları destekler niteliktedir (Toker, Erdem ve Özşarlak, 2017; Demirhan, 2017). Twitter'da çoğu siyasi parti ve aktör hesabının herkese açı olmasından ve buradaki içeriklerin hesabı olmayan kullanıcılar tarafından da görüntülenebilmesinden ötürü bu platform, herkes için erişilebilir konumdadır. Ayrıca, kullanımının hashtag özelliği sayesinde konulara odaklanması ve retweet özelliğiyle, siyasi içeriklerin yalnızca takipçiler ağıyla sınırlı kalmasının önüne geçmektedir (Demirhan, 2017, s. 264-265). Yapılan çalışmalarda yerel politikacıların siyasal iletişim için Facebook'u daha çok kullandığı, ulusal politikacıların ise Twitter'ı daha çok tercih ettiği tespit edilmiştir (Larson ve 
Skogerbo, 2018). Özellikle yerel seçimlere ilişkin kampanyalarda Twitter kullanımı halen çok fazla tercih edilmemektedir (Toker vd., 2017). Bu durumda Facebook'un, özellikle yerel siyaset için daha etkili olarak düşünülürken, Twitter' ın ulusal düzeyde siyaset adına daha etkili olduğu değerlendirilmiştir. Zira Facebook ve Twitter, siyasi parti ve aktörlerin seçmenlere doğrudan ulaşmasını, destekçileri harekete geçirmesini ve kamu gündemini etkilemesini sağlamaktadır (Stier vd., 2018, s.50).

Politikacıların genel olarak kendi programların duyurmak, partilerinin ya da liderlerinin söylemini paylaşmak, demeçler vermek ve bazı zamanlarda e-miting yapmak adına Twitter'ı daha çok kullandıkları da bilinmektedir (Yetkin, 2019, s. 386). Diğer taraftan, Facebook'un özellikle genç bireyler tarafından seçim dönemlerinde siyasal olaylar ve etkinlikler hakkında bilgi toplamak, iletişim kurmak, mesaj göndermek ve/veya almak için yararlanılan bir kitle iletişim aracı olarak kullanıldığı bilinmektedir (Balcı ve Sarıtaş, 2015, s. 531). Dolayısıyla bireylere yönelik siyasal katılım ve siyasal ilgi düzeyinin Facebook ve Twitter' da bireysel kullanım amaçlarından ötürü farklılaşabileceği değerlendirilmektedir. Whatsapp ise yukarıda da bahsedildiği üzere siyasal ifade açısından önemli bir alan oluşturması bakımından daha yakından incelemeye değerdir. Sonuç olarak potansiyel seçmenin hali hazırda toplandığ 1 sosyal medyanın, siyaset üretiminin temel araçlarından biri olarak her geçen gün giderek daha fazla önem kazanacağı söylenebilir (Bayraktutan vd., 2014, s. 65).

\section{Sınırlılıklar ve İleri Araştırmalar}

Bu çalışma 2020 yılı itibariyle Türkiye'de en fazla kullanılan beş sosyal medya platformunu kullanan 493 katılımonın verisiyle gerçekleştirilmiştir. Sosyal medya beş platformla sınırlandırılarak siyasal ifade amaçlı kullanım, siyasal katılım, siyasal ilgi ve bu amaçla kullanılan sosyal medya platformları incelenmiştir. Bu platformlar dışında kalan sosyal medya mecralarının da ilgili değişkenler çerçevesinde incelenmesi, çalışmanın bulgularının genişletilmesine olanak tanıyacaktır. İleride yapılacak çalışmalarda siyasal ifade amaçlı sosyal medya kullanım düzeyi açısından platformlara yönelik içerikler özelinde bir çalışma yapılabilir. Böylelikle siyasal iletişim sürecinde hangi düzeyin ne tür içerikle daha çok etkileşime girdiği tespit edilerek siyasal içerikkatılım ve siyasal içerik-ilgi ilişkisi incelenebilir. 


\title{
EXTENDED ABSTRACT
}

\section{The Role of Social Media Usage Level for Political Expression on Political Interest and Participation: A Field Study in the Context of Social Media Platforms}

\author{
İbrahim Halil Yaşar \\ Dicle University, Faculty of Communication
}

In democratic societies, individuals are expected to deal with issues that directly or indirectly concern them. In order for individuals to have a high level of interest and to participate in political processes, they should have a positive judgment and feel that the system is sensitive to their own needs. Political interest draws attention to the extent to which the individual is concerned with actors such as the political establishment, parliament, government and opposition, and the activities taking place in this field. Political participation is closely related to this interest that the individual establishes with the system. Within the framework of this relationship, political participation can manifest itself in various forms and dimensions, from following political events and government policies, taking political action, talking and discussing political issues, voting, persuading to vote, being a candidate and participating in political decision-making mechanisms. Social media platforms differ from traditional channels because they are two-sided and interactive. These channels, which serve corporate and individual use, offer almost everyone a space to express themselves. While the unique integrated structure of the network allows the content to be spread on different platforms very quickly, ordinary people can turn into micro broadcasters.

Studies have determined that there is a relationship between the presence of a political candidate on social media in election campaigns and the visibility of the political party as a whole by the voters, and the use of social media in political election campaigns has become a fundamental feature, especially in today's democracies. Because individuals increasingly started to use social media to reach political news and share their views. Another important role 
social media plays in the relationship between individual and politics is actually the change it creates for the individual. In this way, the individual has a channel where he can explain his thoughts about what is happening in the political field. This form of use, which is also described as the use of social media for political expression, represents individuals' expressing their opinions and approaches on political issues and using social media platforms for various purposes such as supporting or criticizing political parties / candidates and leaders and / or their approach to issues. The reasons such as the number of users of each platform, the rapid spread of the content thanks to the integrated structure of the network, the automatic recording of the data so that it can be processed make social media extremely useful for political communication. Thus, political parties can increase their visibility with their campaigns including social media.

In this study, political participation and political interests of social media users in Turkey, it was asked to examine in terms of social media use for political expression. The aforementioned review was carried out for the five most used social media platforms as of 2020 in Turkey. The use of social media for political expression was grouped according to the level of use and the relationship between the relevant groups and demographic characteristics was examined. Thus, it was tried to reveal what kind of pattern each level exhibits. In addition, in terms of social media platforms that users used to share their feelings and thoughts and / or get ideas on political issues, political interest and political participation were also examined, and how the relevant variables differ in the specific platforms was examined. The study differs from other studies by grouping social media according to the level of use for political expression. Thus, it provides a broad framework in terms of both focusing on the variables of political participation and political interest, and examining the levels in terms of both demographic features and social media platforms used to share feelings and thoughts and / or get ideas on political issues.

In the study, the data of 493 people who were reached by using convenience sampling were analyzed. In general, the findings of the study show that social media platforms, which both individuals and corporate structures benefit from in different ways, are an area of use in the political field as well as in other areas. The fact that the WhatsApp platform was used more to share thoughts or gain ideas on political issues showed that the relevant platform 
constituted an important area in terms of political expression. In the study, it was determined that the level of political interest was generally high, while the use of social media for political participation and political expression was relatively low. As a result of the examination of the demographic characteristics in terms of the level of social media use for political expression, it was determined that gender, age and education level did not have a significant relationship with the levels. Individuals used social media at similar levels for political expression, regardless of their gender, age and educational background. The differentiation of political participation and political interest on Facebook, Twitter and Whatsapp platforms in terms of social media platforms used to share feelings and thoughts and / or get ideas on political issues, indicated the importance of these platforms in terms of political communication.

The fact that political participation and political interest were seen on Twitter at the highest level supports previous studies. Twitter is accessible to everyone, since most political parties and actor accounts on Twitter are public and its content can be viewed by users who do not have an account. In addition, the use of hashtag feature allows it to focus on topics and retweet, preventing political content from being limited to the followers only. As a result, social media, where potential voters are already gathered, will gain more and more importance every day as one of the basic tools of political area.

\section{Kaynakça / References}

Advan, A. (2016). Kobani actions in the context of social movements 6-10 October 2014 Events - Diyarbakır Case. W. Sayers ve M. Avc1(Der.), Law and order in Turkish society içinde (s. 167-174). London: AGP Research.

Akgün, B. (2001). Türkiye'de siyasal güven: Nedenleri ve sonuçları. Selçuk Üniversitesi İktisadi ve İdari Bilimler Fakültesi Dergisi, 56(4), 1-23.

Akmeşe, E. ve Akmeşe, Z. (2020). Mizahla estetize edilen egemen ideolojinin tezahürü: Muhsin Bey. Sosyal, Beşeri ve İdari Bilimler Dergisi, 3(3), 194-207.

Arifin, W. N. (2015). The graphical assessment of multivariate normality using SPSS. Education in Medicine Journal, 7(2), 71-75.

Arklan, Ü. (2016). Sosyal medyanın siyasal amaçıı kullanımı: A ̆̆ kuşağının kullanım alışkanlıkları üzerine bir araştırma. Gümüşhane Üniversitesi İletişim Fakültesi Elektronik Dergisi, 4(2), 618-657. 
Avcl, S. F. (2019, Ocak 24). Dijital kampanyalar yerel seçimlerde belirleyici olacak. Hürriyet Gazetesi. 19 Temmuz 2020 tarihinde, https://www.hurriyet.com.tr/teknolojidiijital-kampanyalar-yerel-secimlerde-belirleyici-olacak-41092687 adresinden erişildi.

Balcı, Ş. ve Sarıtaş, H. (2015). Facebook ve siyasal katılım: 2014 yerel seçimleri araştırması. Türkiyat Araștrmalan Dergisi, 35, 511-535.

Başaran, Y.K. (2017). Sosyal bilimlerde örnekleme kuramı. Akademik Sosyal Araştırmalar Dergisi, 47(5), 480-495.

Baykal, D. (1970). Siyasal katılma: Bir dauranış incelemesi. Ankara: Üniversitesi Siyasal Bilgiler Fakültesi Yayınları.

Bayraktutan, G., Binark, M., Çomu, T., Doğu, B., İslamoğlu, G. ve Aydemir, A. (2014). Siyasal iletişim sürecinde sosyal medya ve Türkiye'de 2011 genel seçimlerinde Twitter kullanım. Bilig, 68, 59-96.

Boulianne, S. (2015). Social media use and participation: A meta-analysis of current research. Information, Communication \& Society, 18(5), 524-538.

Bright, J., Hale, S., Ganesh, B., Bulovsky, A., Margetts, H. ve Howard, P. (2020). Does campaigning on social media make a difference? Evidence from candidate use of Twitter during the 2015 and 2017 U.K. elections. Communication Research, 47(7), 988-1009. doi: 10.1177/0093650219872394

Campbell, A., Gurin, G., ve Miller, W. E. (1954). The voter decides. Evanston, IL: Row, Peterson and Company.

Canbaz, S., Eyidiker, U. ve Poyraz, E. (2019). Siyasal kathlım veüniversite öğrencilerinin siyasal kathlıma bakışs: Babaeski Meslek Yüksekokulu örneği. Social Sciences Studies Journal, 5(35), 2537-2551.

Castells, M. (2016). Illetişim gücü. (E. Kılıç, Çev.). İstanbul: İstanbul Bilgi Üniversitesi Yayınları. (Orijinal eserin yayın tarihi 2009).

Coleman, K. M. ve Davis C. L. (1976). The structural context of politics and dimensions of regime performance: Their importance for the comparative study of political efficacy. Comparative Political Studies, 9(2), 189-206.

Creswell, J. W. (2014). Educational research: Planning, conducting, and evaluating quantitative and qualitative research. New York: Pearson.

Dahl, R. A. (2017). Demokrasi üzerine. (B. Kadığlu, Çev.). Ankara: Phoenix Yayınevi. (Orijinal eserin yayın tarihi 1998).

Dahlgren, P. (2007). Young citizens and new media: Learning for democratic participation. New York: Routledge.

Demirhan, K. (2017). Türkiye'de 2017 anayasa referandumu sürecinde siyasal iletişim aracı olarak Twitter kullanımı. Erciyes IIletişim Dergisi, 5(2), 262-280. 
Dimitrova, D. V. ve Bystrom, D. (2013). The effects of social media on political participation and candidate image evaluations in the 2012 Iowa caucuses. American Behavioral Scientist, 57(11), 1568-1583. doi: 10.1177/0002764213489011

Gerodimos, R. ve Justinussen, J. (2015). Obama's 2012 Facebook campaign: Political communication in the age of the like button. Journal of Information Technology $\mathcal{E}$ Politics, 12(2), 113-132. doi: 10.1080/19331681.2014.982266

Glenn, N. D. (1968). Aging, voting, and political interest. American Sociological Association, 33(4), 563-575.

Hair, J. F., Black, W. C., Babin, B. J. ve Anderson, R. E. (2014). Multivariate data analysis. USA: Pearson Educated Limited.

Hooghe, M. ve Marien, S. (2013). A comparative analysis of the relation between political trust and forms of political participation in Europe. Journal of European Societies, 15(1), 131-152.

Kahne, J. ve Middaugh, E. (2012). Digital media shapes youth participation in politics. Phi Delta Kappan, 94(3), 52-56. doi: 10.1177/003172171209400312

Kalaycı, Ş. (2017). SPSS uygulamalı çok değişkenli istatistik teknikleri. Ankara: Dinamik Akademi Yayın Dağıtım.

Kalaycıoğlu, E. (1983). Karşılaştırmalı siyasal katllma: siyasal eylemin kökenleri üzerine bir inceleme. İstanbul: İstanbul Üniversitesi SBF Yayın.

Kalaycıoğlu, E. (2013). Siyasal katılımm anatomisi. Bilim Akademi Derneği Dergissi, 34, 148179.

Larsson, A. ve Skogerbo, E. (2018). Out with the old, in with the new? Perceptions of social (and other) media by local and regional Norwegian politicians. New Media \& Society, 20(1), 219-236. doi: 10.1177/1461444816661549

Lilleker, D. G. (2013). Siyasal iletişim temel kauramlar. İstanbul: Kaknüs Yayınları.

Loader, B. D., Vromen, A. ve Xenos, M. A. (2014). The networked young citizen: Social media, political participation and civic engagement. Information, Communication and Society, 17(2), 143-150. doi: 10.1080/1369118X.2013.871571

Lorenzo Rodríguez, J. ve Garmendia Madariaga, A. (2016). Going public against institutional constraints? Analyzing the online presence intensity of 2014 European Parliament election candidates. European Union Politics, 17(2), 303-323. doi: $10.1177 / 1465116515618252$

Milbrath, L. W. (1965). Political participation: How and why do people get involved in politics? Chicago: Rand McNally Company.

Milbrath, L. W. ve Goel, M. L. (1977) Political participation. Chicogo: Rand McNally Company. 
Neuman, W. R. (2018). Dijital fark: Gündelik hayatta dijitalleşme ve medya etkileri kuramı. (G. Metin, Çev.). İstanbul: The Kitap Yayınları. (Orijinal eserin yayın tarihi 2016).

Nulty, P., Theocharis, Y., Popa, S. A., Parnet, O. ve Benoit, K. (2016). Social media and political communication in the 2014 elections to the European Parliament. Electoral Studies, 44, 429-444. doi: 10.1016/j.electstud.2016.04.014

Olkun, E., Yüksel, E. ve Akdemir, G. (2018). Sosyal medya ve siyasal katılım: 2017 referandumunda bir saha araştırması. Uluslararası Sosyal Araştırmalar Dergisi, 60(11), 991-1000.

Öztekin, A. (2001). Siyaset bilimine giriş, toplum devlet parlamento hükümet kamu yönetimi. Ankara: Siyasal Kitabevi.

Pallant, J. (2011). SPSS survival manual: A step by step guide to data analysis using SPSS. New York: Open University Press.

Schulz W. (2005). Political efficacy and expected political participation among lower and upper secondary students: a comparative analysis with data from iea civic education study. ECPR Generel Conference in Budapest, 8-10 September.

Sposito, V. A., Hand, M. L. veSkarpness, B. (1983). On the efficiency of using the sample kurtosis in selecting optimal lpestimators. Communications in Statistics-Simulation and Computation, 12(3), 265-272.

Stier, S., Bleier, A., Lietz, H. ve Strohmaier, M. (2018). Election campaigning on social media: Politicians, audiences, and the mediation of political communication on Facebook and Twitter. Political Communication, 35(1), 50-74. doi: 10.1080/10584609.2017.1334728

Toker, H., Erdem, S. veÖzşarlak, P. (2017). 2015 Haziran ve Kasım seçimlerinde siyasal eğilim: Yeni bir kamuoyu ölçümleme aracı olarak Twitter. Erciyes Illetişim Dergisi, 5(1), 96-116.

Topbaş, H. (2010). David Easton'un siyasal sistem kuramı bağlamında siyasal katılma: Erzurum seçmeni üzerine bir araştırma. İetişim Kuram ve Araştırma Dergisi, 30, 81-111.

Ünal, R. (2019). Anaakım medyada kullanıcı türevli içeriğin izini sürmek: NTV ve Star TV Whatsapp ihbar hatları üzerine bir inceleme. Mersin Üniversitesi Sosyal Bilimler Enstitüsü Dergisi, 2(2), 34-43.

Verba, S., ve Nie, N. H. (1972). Participation in America: Political democracy and social equality. New York, NY: Harper \& Rowe.

Vitak, J., Zube, P., Smock, A., Carr, C. T., Ellison, N. ve Lampe, C. (2011). It's complicated: Facebook users' political participation in the 2008 election. Cyberpsychology, Behavior, and Social Networking, 14(3), 107-114

Yaşar, İ. H. (2020). Sosyal medya ve siyaset. Ankara: Orion Akademi. 
Yavaşçalı, A. H. ve Uğurhan, Y. Z. C. (2019). Neden kullanıclar Twitch TV üzerinde yayıncılara bağış yapar? Twitch TV kullanıcları üzerinde ampirik bir araştırma. Gümüşhane Üniversitesi Illetişim Fakültesi Elektronik Dergisi, 7(2), 646676. doi: 10.19145/e-gifder.561050

Yetkin, B. (2019). 2019 yerel seçimlerinde adayların Twitter kullanımı. Hacettepe Üniversitesi Illetişim Fakültesi Kültürel Çalş̧malar Dergisi, 6(2), 382-405.

\section{Kaynakça Bilgisi / Citation Information}

Yaşar, İ. H. (2021). Siyasal ifade amaçlı sosyal medya kullanım düzeyinin siyasal ilgi ve katılım üzerinde rolü: Sosyal medya platformları bağlamında bir saha araştırması. OPUS-Uluslararası Toplum Araştırmalar Dergisi, 17(34), 1173-1203. DOI: 10.26466/opus.816083 